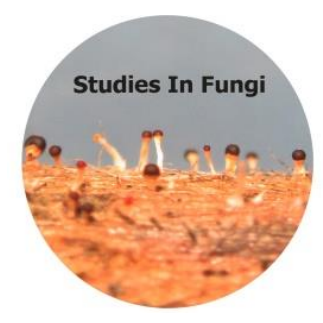

Studies in Fungi 3(1): 176-186 (2018) www.studiesinfungi.org ISSN 2465-4973 Article

Doi 10.5943/sif/3/1/18

Copyright $\odot$ Institute of Animal Science, Chinese Academy of Agricultural Sciences

\title{
Biotechnological potential of agro-industrial wastes for protein enrichment by solid-state fermentation using Aspergillus niger
}

\author{
Adu SK ${ }^{2}$, Yafetto $\mathrm{L}^{1 *}$, Ofosuhene $\mathrm{A}^{\mathbf{1}}$, Offei-Affedzie $\mathrm{T}^{\mathbf{1}}$, Adu $\mathrm{S}^{1}$ and Ntibe $\mathrm{TN}^{1}$ \\ ${ }^{1}$ Department of Molecular Biology and Biotechnology, School of Biological Sciences, College of Agriculture and \\ Natural Sciences, University of Cape Coast, Cape Coast, Ghana \\ ${ }^{2}$ Department of Animal Science, School of Agriculture, College of Agriculture and Natural Sciences, University of Cape \\ Coast, Cape Coast, Ghana
}

Adu SK, Yafetto L, Ofosuhene A, Offei-Affedzie T, Adu S, Ntibe TN 2018 - Biotechnological potential of agro-industrial wastes for protein enrichment by solid-state fermentation using Aspergillus niger. Studies in Fungi 3(1), 176-186, Doi 10.5943/sif/3/1/18

\begin{abstract}
This study is to assess the biotechnological potential of agro-industrial wastes of pineapple (Ananas comosus), sweet potato (Ipomoea batatas) and watermelon (Citrullus lanatus) for protein enrichment by solid-state fermentation using Aspergillus niger. Spore suspensions of A. niger were prepared with potato dextrose broth that had been supplemented with sodium chloride, ammonium nitrate and thiamine, and adjusted to $\mathrm{pH}$ of 5 . Initial protein contents of sterile and non-sterile wastes of the pineapple, sweet potato, and watermelon were determined by the Kjeldahl method. The remaining sterile and non-sterile wastes was inoculated with spore suspensions of $A$. niger and incubated at temperature of $24^{\circ} \mathrm{C}$ under conditions of solid-state fermentation for 14 days. Protein contents of the inoculated sterile and non-sterile wastes were determined after 7 and 14 days. The sterile wastes of pineapple, sweet potato and watermelon recorded initial percentage protein contents of 4.37, 4.39, and 10.89, respectively, whereas their corresponding non-sterile wastes recorded initial percentage protein contents of 3.76, 4.00, and 10.16, respectively. The results further show that percentage increase in protein content of sterile wastes after 14 days of fermentation were pineapple, $35.01 \%$; sweet potato, $27.60 \%$; and watermelon, $64.40 \%$. Percentage increase in protein content of non-sterile wastes after 14 days of fermentation were pineapple, $72.34 \%$; sweet potato, $85.25 \%$; and watermelon, $80.51 \%$. These findings affirm the biotechnological potential of pineapple, sweet potato and watermelon wastes and the importance of fungi as agents for protein enrichment of agro-industrial wastes.
\end{abstract}

Key words - agro-based wastes - fungal biotechnology - nutrient enrichment - solid-substrate fermentation - value addition

\section{Introduction}

Agro-based industries all over the world rely heavily on the supply of raw materials from farmlands. These agricultural, animal feed, confectionary, food, juice, meat, and paper industries, after production generate millions of metric tons of agro-industrial wastes that are improperly disposed of and cause environmental pollution and serious health threats to animals including humans (Rodríguez-Couto 2008, Belewu \& Babalola 2009, Ezekiel \& Aworh 2013, Sadh et al. 2018). This notwithstanding, agro-industrial wastes such as apple pomace, cassava bagasse, coffee 
pulp and husk, sugarcane bagasse, sugar beet pulp, among others, are exploited and utilized in large quantities by microorganisms to produce and develop industrial products because of their high nutrient contents (Rivas et al. 2008, Nigam et al. 2009, Paepatung et al. 2009, El-Tayeb et al. 2012, Martin et al. 2012, Weshahy \& Rao 2012, Motte et al. 2013, Ballesteros et al. 2014, Sadh et al. 2018). The utilization of these agro-industrial wastes for the production of useful products emphasizes their biotechnological potentials for efficient value addition (Pandey \& Soccol 2000, Pandey et al. 2000a, b, c, Soccol \& Vandenberghe 2003).

Value addition is mostly accomplished through solid-state fermentation, a biotechnological process that employs microorganisms to grow on non-soluble or solid substrates that contain complex polymers like lignin, pectin, and lignocellulose to produce useful products (Iyayi \& Losel 2001, Duru \& Uma 2003, Correia et al. 2007, Gélinas \& Barrette 2007, Bhargav et al. 2008, Bayitse et al. 2013, Ezekiel \& Aworh 2013, Aggelopoulos et al. 2014, Sadh et al. 2018, Yafetto 2018). Some of these useful products that are derived from the agro-industrial wastes through solidstate fermentation using fungi include the following: (i) bioethanol (Ofoefule \& Uzodinma 2009, Paepatung et al. 2009, Avci et al. 2013, Duhan et al. 2013, Kumar et al. 2014, 2016, Saini et al. 2015, Maiti et al 2016, Mushimiyimana \& Tallapragada 2016); (ii) antioxidants (Duda-Chodak \& Tarko 2007, Nigam et al. 2009, Parashar et al. 2014, Sadh et al. 2017a, b, c); (iii) antibiotics (Asagbra et al. 2005, Vastrad \& Neelagund 2012); (iv) enzymes (Ellaiah et al. 2002, Kalogeris et al. 2003, Topakas et al. 2004, Negi \& Banerjee 2009, Buenrostro et al. 2013, Duhan et al. 2013, Kumar et al. 2013, Mathew et al. 2015, Oliveira et al. 2017, Saharan et al. 2017); (v) mushrooms (Chang 2006, Murthy \& Manonmani 2008, Babu \& Subhasree 2010, Siqueira et al. 2011, Akinyele et al. 2012, Randive 2012, Kumhomkul \& Panich-pat 2013); and (vi) single cell proteins (Mondal et al. 2012, Aggelopoulos et al. 2014).

In Ghana, there is a problem dealing with large quantities of agro-industrial wastes that are generated from agro-processed raw materials, which the agro-industries essentially do not have any use for. Rather, these wastes are poorly disposed of into the environment, either at the backyards of the agro-industrial plants or are cart away by waste management companies to landfills to rot. This situation of lack of proper management of agro-industrial waste is taken advantage of by some peasant farmers and animal breeders who cart these wastes to their farms for use as manure for their vegetable gardens or as animal feed for their livestock (Fig. 1).

In recent decades, in West Africa, some initial investigations have focused on the potential biotechnological applications of fungi to improve the nutritional and economic values of cassava and cocoyam into animal feed (Iyayi \& Losel 2001, Duru \& Uma 2003, Bayitse et al. 2013, Ezekiel \& Aworh 2013, Bayitse et al. 2015, Yafetto 2018). Meanwhile, corn stalks, coffee pulp, maize cobs, oil palm pulp, sawdust, and peels of mango, pineapple, plantain, sweet potato, and watermelon present themselves as potential candidates for use as agro-industrial wastes whose nutritional and economic values can be increasingly improved to produce useful products like animal feed to support the poultry and fishery sectors of the Ghanaian economy (Kumar et al. 2003, Villas-Boas et al. 2003, Shah et al. 2005, Yafetto 2018). This present study therefore aimed to assess the biotechnological potential of pineapple, sweet potato and watermelon as agro-industrial wastes for protein enrichment by solid-state fermentation using A. niger. Findings from this study continues to expand the frontiers of biotechnological application of fungi in the production of protein-enriched agro-industrial products in Ghana and West Africa.

\section{Materials and Methods}

\section{Pineapple, sweet potato and watermelon}

Agro-industrial wastes of pineapple peels, sweet potato peels and watermelon rind were obtained from local farmers, and small-scale fruit-processing industries in Cape Coast, which once served as the capital of the Gold Coast, now Ghana (Yafetto \& Osei-Bonsu 2017). 


\section{Aspergillus niger}

Aspergillus niger used in this study was isolated through the open plate method. Petri plates with potato dextrose agar (PDA) medium (200 g Irish potato; $20 \mathrm{~g}$ dextrose; $20 \mathrm{~g}$ agar; $1000 \mathrm{ml}$ distilled water; autoclaved at a pressure of $1.1 \mathrm{~kg} / \mathrm{cm}^{2}$ at $121^{\circ} \mathrm{C}$ for 15 minutes) were exposed to air for about 5 minutes at the forecourt of the School of Biological Sciences, University of Cape Coast. The exposed Petri plates were covered and incubated at $24^{\circ} \mathrm{C}$ for 7 days until growth of different fungi were observed. A. niger was carefully isolated and sub-cultured on PDA at $25^{\circ} \mathrm{C}-30^{\circ} \mathrm{C}$ for 7 days to obtain pure cultures. The A. niger was identified using morphological and other growth features with the aid of identification manuals (Ellis et al. 2007, Pitt \& Hocking 2009, Sharma \& Pandey 2010, Watanabe 2010, Campbell et al. 2013). The pure cultures of A. niger were then preserved as stock cultures on slants in McCartney tubes at $4^{\circ} \mathrm{C}$, and sub-cultured fortnightly. Irish potatoes used to prepare both PDA and potato dextrose broth (PDB) for this study were obtained from a local Ghanaian grocery.

\section{Conidia suspension of $A$. niger as inoculum}

PDB medium (200 g Irish potato; $20 \mathrm{~g}$ dextrose; $1000 \mathrm{ml}$ distilled water; autoclaved at a pressure of $1.1 \mathrm{~kg} / \mathrm{cm}^{2}$ at $121^{\circ} \mathrm{C}$ for 15 minutes) was supplemented with $2 \mathrm{~g}$ Ammonium nitrate, $8 \mathrm{~g}$ Sodium chloride and $400 \mu \mathrm{g}$ Thiamine with $\mathrm{pH}$ adjusted to 5 based on methods used and results obtained from nutritional requirements studies of A. niger reported by Yafetto (2018). The PDBamended media were used to prepare conidial suspension of A. niger to inoculate pineapple, sweet potato and watermelon wastes using methods by Guarro et al. (1998), Yalemtesfa et al. (2010).

\section{Estimation of percentage protein content of pineapple, sweet potato and watermelon}

Sterile and non-sterile pineapple, sweet potato and watermelon wastes used in the estimation of protein contents were cleaned and prepared as described by Yafetto (2018). Initial percentage nitrogen $\left(\% \mathrm{~N}_{2}\right)$ of the sterile and non-sterile agro-industrial wastes were determined using the Kjeldahl method (Kjeldahl 1883), after which the percentage $\mathrm{N}_{2}\left(\% \mathrm{~N}_{2}\right)$ contents of the wastes were determined after 7 and 14 days of fermentation and subsequently used to estimate the percentage protein contents (\% Protein) of the substrates as follows:

$$
\% \text { Protein content }=\% \mathrm{~N}_{2} \times 6.25 \text {, }
$$

where 6.25 is the protein conversion factor.

Percentage increase in the protein content of the sterile and no-sterile wastes of the pineapple, sweet potato and watermelon were determined as follows:

Percentage Increase of Protein Content $=\underline{\text { Final Protein Content }- \text { Initial Protein Content X 100\% }}$ Initial Protein Content

\section{Results}

Protein enrichment of fermented sterile substrates of pineapple, sweet potato and watermelon

Sterile wastes of pineapple, sweet potato and watermelon recorded initial \% protein contents of 4.37, 4.39, and 10.89, respectively (Fig. 2). Percentage protein contents of sterile wastes of pineapple and sweet potato increased after 7 days of fermentation, but decreased after 14 days (Fig. 2). However, the percentage protein contents of watermelon waste steadily increased up to 14 days of fermentation (Fig. 2). The highest \% protein content was determined in watermelon waste (17.90), whereas the lowest \% protein content was determined in sweet potato wastes (5.60) after 14 days of fermentation (Fig. 2).

Percentage increase in protein contents of sterile pineapple, sweet potato and watermelon wastes after 14 days of fermentation were $35.01 \%, 27.60 \%$ and $64.40 \%$, respectively (Table 1 ). 
Interestingly, there was an overwhelming increase in percentage protein content in sterile sweet potato waste (171.10\%) after 7 days of fermentation, which dropped drastically to $27.60 \%$ after 14 days of fermentation (Table 1).

Protein enrichment of fermented non-sterile substrates of pineapple, sweet potato and watermelon

Non-sterile wastes of pineapple, sweet potato and watermelon recorded initial \% protein content of 3.76, 4.00, and 10.16, respectively (Fig. 3). Percentage protein content of the non-sterile wastes increased after 7 days of fermentation; the percentage protein content in the three agroindustrial wastes decreased after 14 days of fermentation (Fig. 3). The highest \% protein content was determined in watermelon waste (21.70), whereas the lowest $\%$ protein content was determined in pineapple (6.48) (Fig. 3). Percentage increases in protein content of non-sterile pineapple, sweet potato and watermelon wastes after 14 days of fermentation were $72.34 \%, 85.25 \%$, and $80.51 \%$, respectively (Table 1).

Table 1 Percentage (\%) increase in protein content of agro-industrial wastes after 7 days and 14 days of fermentation.

\begin{tabular}{lllllll}
\hline & \multicolumn{2}{l}{ Percentage increase in protein content } \\
\cline { 2 - 7 } & \multicolumn{2}{l}{ Pineapple } & \multicolumn{2}{l}{ Sweet Potato } & \multicolumn{2}{l}{ Watermelon } \\
\hline Nature of Substrate & 7 Days & 14 Days & 7 Days & 14 Days & 7 Days & 14 Days \\
\hline Sterile wastes & 42.60 & 35.01 & 171.10 & 27.60 & 51.51 & 64.40 \\
\hline Non-sterile wastes & 81.65 & 72.34 & 108.75 & 85.25 & 113.60 & 80.51 \\
\hline
\end{tabular}

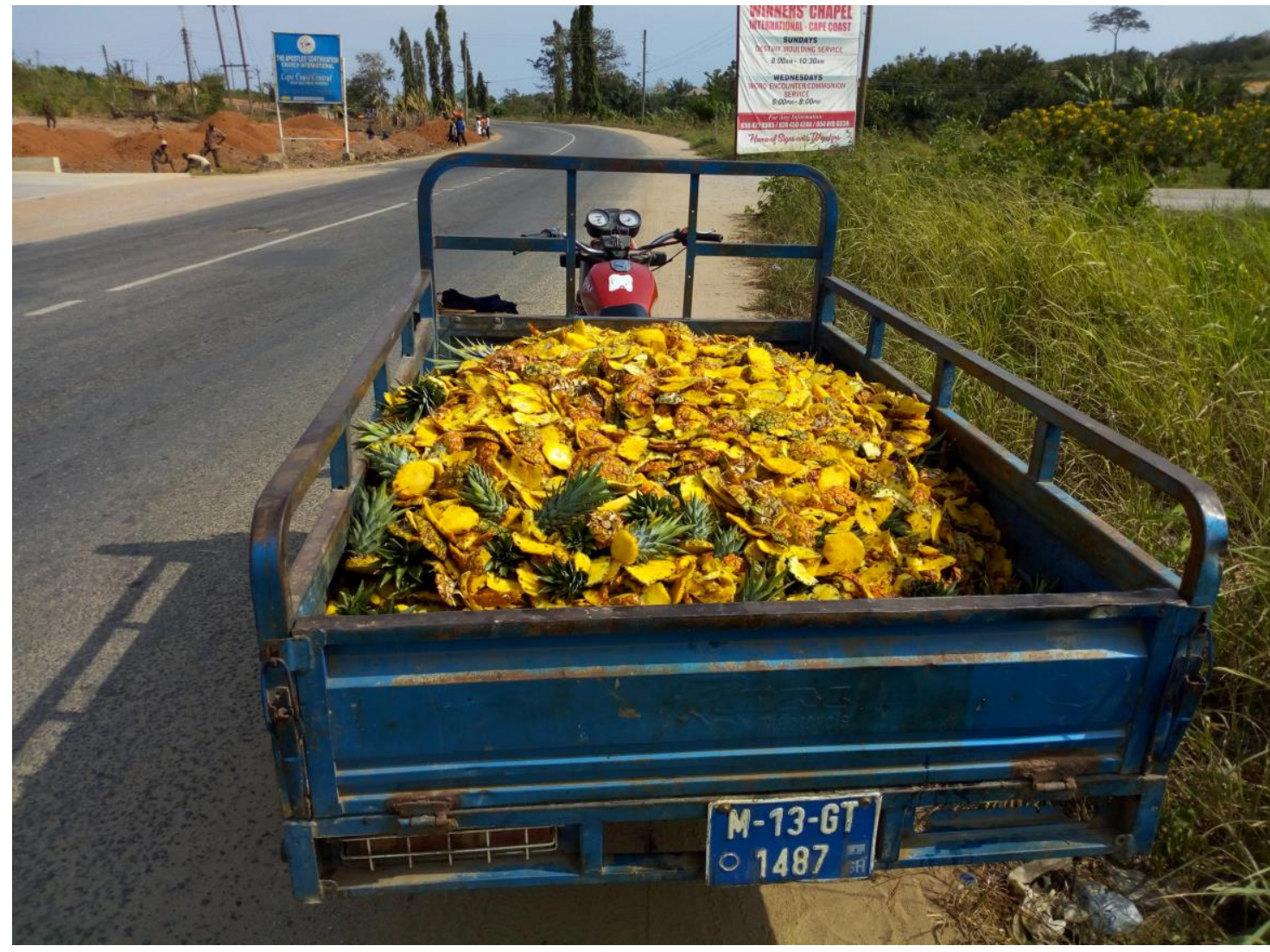

Fig. 1 - Pineapple wastes carted from a small-scale pineapple juice factory in a tricycle by a farmer to a piggery. Photo credit: Levi Yafetto (March, 2018). 


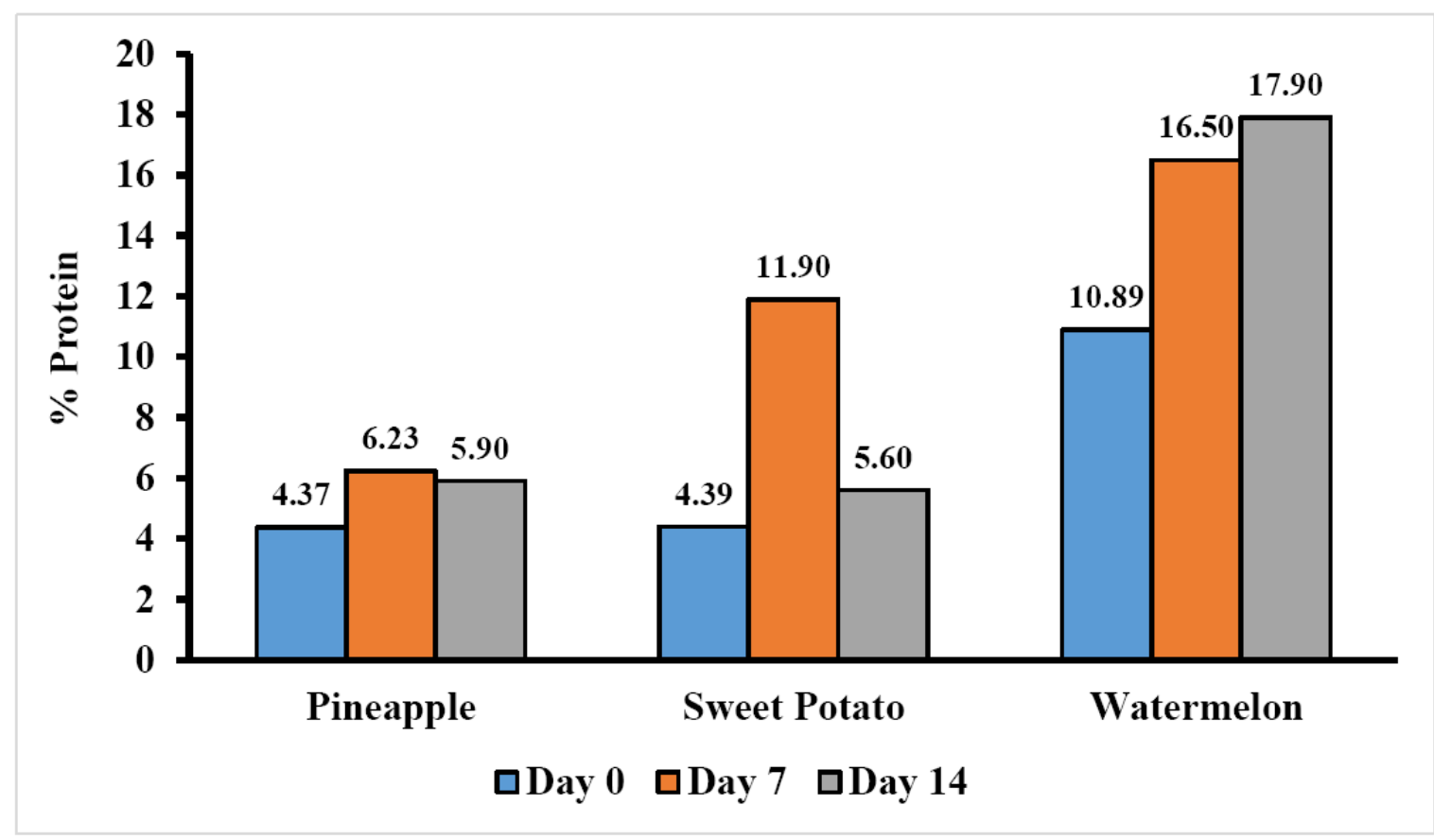

Fig. 2 - Percentage protein contents of sterile pineapple, sweet potato and watermelon wastes after solid-state fermentation with $A$. niger.

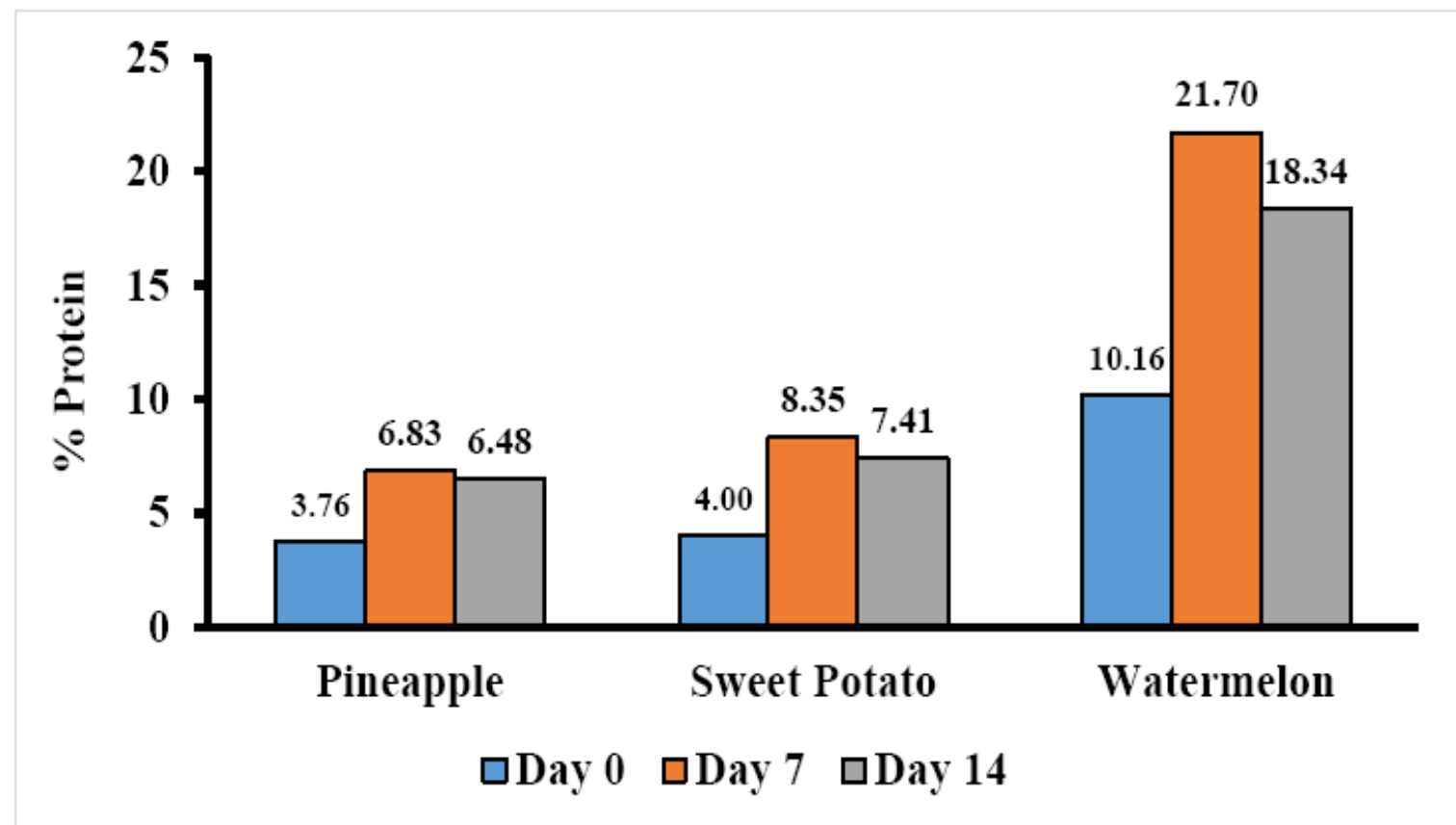

Fig. 3 - Percentage protein contents of non-sterile pineapple, sweet potato and watermelon wastes after solid-state fermentation with A. niger.

\section{Discussion}

Findings from this study revealed three things: (i) that the three agro-industrial wastes pineapple, sweet potato and watermelon - are suitable for protein enrichment by solid-state fermentation using $A$. niger, (ii) that the pineapple, sweet potato and watermelon wastes successfully supported growth of $A$. niger, and (iii) that PDB-amended medium was an efficient and a reliable medium that could be used as a source of inoculum to study other agro-industrial wastes as demonstrated by Yafetto (2018). Other studies have employed different fungal species, 
media and substrates that have been equally efficient with solid-state fermentation (Mitchell et al. 1988, Tsen et al. 2000, Pandey et al. 2000a, Duru \& Uma 2003, Gao et al. 2007, Gao \& Liu 2010, Ezekiel \& Aworh 2013, Nagadesi \& Arya 2013, Gao 2014, Bayitse et al. 2015).

Findings from this study amply demonstrate that the protein contents of both sterile and nonsterile wastes of pineapple, sweet potato and watermelon have the biotechnological potential to be enriched with $A$. niger under conditions of solid-state fermentation. For example, percentage increase in protein contents of sterile pineapple, sweet potato and watermelon wastes after 14 days of fermentation were $35.01 \%, 27.60 \%$ and $64.40 \%$, respectively; percentage increase in protein contents of non-sterile pineapple, sweet potato and watermelon wastes after 14 days of fermentation were overwhelmingly higher at $72.34 \%, 85.25 \%$, and $80.51 \%$, respectively. After just 2 days of solid-state bioprocessing, Correia et al. (2007) reported a $22.00 \%$ protein content in pineapple waste with Saccharomyces cerevisiae. A more decreased crude protein contents have been reported for pineapple wastes after 2, 3 and 4 days of fermentation with A. niger and Trichoderma viride (Omwango et al. 2013). Also, Yafetto (2018) reported lower \% protein content in cassava after 8 days of fermentation; Aruna et al. (2017) reported a range of protein content between $6.60-11.08 \%$ in yam peels after 4 days of fermentation with Saccharomyces cerevisiae. These findings by Correia et al. (2007), Omwango et al. (2013), Aruna et al. (2017), Yafetto (2018) may suggest that protein content of agro-industrial wastes could increase substantially with extended days for fermentation. This suggestion is supported by the higher protein contents reported in this study when fermentation of pineapple, sweet potato and watermelon wastes were extended to 14 days (Table 1, Figs 2, 3).

Bayitse et al. (2015) reported $36.90 \%$ and $48.10 \%$ protein enrichment of cassava waste after 12 days of fermentation. Similarly, Yalemtesfa et al. (2010) reported protein content of $39.64 \%$ and $31.70 \%$ in orange waste using Chaetomium spp and A. niger, respectively, demonstrating the potential of orange waste for protein enrichment under conditions of solid-state fermentation. Findings by Yang (1988, 1993), and Yang et al. (1993) further revealed varying levels of protein content that ranged between 16.11-34.00\% with mono- and co-cultures of amylolytic fungi.

Although the highest protein contents were surprisingly reported in watermelon among the agro-industrial wastes used in this study, interestingly, it appears there are no reports on protein enrichment of watermelon wastes available in literature. Rather, the use of watermelon seed and rind for value addition into other products have been reported (Al-Sayed \& Ahmed 2013, Wani et al. 2013) This could suggest that the findings on watermelon in this study may be among the first reports in literature on the use of watermelon waste for protein enrichment with fungi using solidstate fermentation. Considering the high protein contents reported here, watermelon wastes could have a huge potential for use in the production of animal feed through the use of fungi.

The increase in protein content recorded for the three agro-industrial wastes in this study gives credence to the ability of $A$. niger to secret enzymes that convert complex starch and nonstarch polysaccharides into simple monomer sugars which are metabolized into proteins (Ezekiel \& Aworh 2013). The higher percentages in protein contents of non-sterile wastes may be attributed to the presence of other microbes, in addition to A. niger, whose metabolic activities collectively contributed to the overall protein enrichment of the wastes. The overall reduction in protein contents reported in both the sterile and non-sterile wastes in this study was observed probably due to the occurrence of proteolysis after some days of fermentation and the depletion of nutrient sources (Correia et al. 2007).

We conclude from this study that pineapple, sweet potato and watermelon wastes have the biotechnological potential for protein enrichment using fungi, and that the findings continue to add to the body of knowledge and the relatively scanty literature available on the use of agro-industrial wastes together with fungi for value addition. It is recommended that future studies should aim to investigate further and explore the biotechnological applications of other fungi such as $T$. viride, and $S$. cerevisiae to enrich agro-industrial wastes using mono- and co-cultures of these fungi. Findings from such studies should provide also more insights into the biotechnological potential of agro-industrial wastes in relation to their use as animal feed. 


\section{Acknowledgments}

The authors are grateful to the technical staff of the Department of Molecular Biology and Biotechnology and the Department of Animal Sciences, University of Cape Coast, Ghana for the technical assistance provided during the study. Many thanks go also to the local Ghanaian farmers and small-scale fruit-processing industries that provided the pineapple, sweet potato and watermelon wastes for this study.

\section{References}

Aggelopoulos T, Katsieris K, Bekatorou A, Pandey A et al. 2014 - Solid state fermentation of food waste mixtures for single cell protein, aroma volatiles and fat production. Food Chemistry $145,710-6$.

Akinyele JB, Fakoya S, Adetuyi CF. 2012 - Anti-growth factors associated with Pleurotus ostreatus in a submerged liquid fermentation. Malaysian Journal of Microbiology 8, 135140.

Al-Sayed HMA, Ahmed AR. 2013 - Utilization of watermelon rinds and sharlyn peels as a natural source of dietary fiber and antioxidants in cake. Annals of Agricultural Sciences 58, 83-95.

Aruna TE, Aworh OC, Raji AO, Olagunju AI. 2017 - Protein enrichment of yam peels by fermentation with Saccharomyces cerevisiae (BY4743). Annals of Agricultural Science 62 (1), 33-37.

Asagbra AE, Sani AI, Oyewole OB. 2005 - Solid state fermentation production of tetracycline by Streptomyces strains using some agricultural wastes as substrate. World Journal of Microbiology Biotechnology 21, 107-114.

Avci A, Saha BC, Dien BS, Kennedy GJ, Cotta MA. 2013 - Response surface optimization of corn stover pretreatment using dilute phosphoric acid for enzymatic hydrolysis and ethanol production. Bioresource Technology 130, 603-612.

Babu PD, Subhasree RS. 2010 - Valuing the suitable agro-industrial wastes for cultivation of $P$. platypus and P. eous. Advances in Biological Research 4, 207-210.

Ballesteros LF, Teixeira JA. Mussatto SI. 2014 - Chemical, functional, and structural properties of spent coffee grounds and coffee silverskin. Food and Bioprocess Technology 7, 3493-3503.

Bayitse R, Oduro W, Aggey M, Selormey G et al. 2013 - Overview of potential biowaste and biobased residues for production of value added products. Ghana Country Report for FP7 Biowaste4SP, Grant Agreement No. 312111.

Bayitse R, Hou X, Laryea G, Bjerre AB. 2015 - Protein enrichment of cassava residue using Trichoderma pseudokoningii (ATCC 26801). AMB Express 5, 80-85.

Belewu MA, Babalola FT. 2009 - Nutrient enrichment of some waste agricultural residues after solid state fermentation using Rhizopus oligosporus. Journal of Applied Bioscience 13, 695699.

Bhargav S, Panda BP, Ali M, Javed S. 2008 - Solid-state fermentation: an overview. Chemical and Biochemical Engineering 22(1), 49-70.

Buenrostro J, Ascacio A, Sepulveda L, De la Cruz R et al. 2013 - Potential use of different agroindustrial by-products as supports for fungal ellagitannase production under solid state fermentation. Foods and Bioproducts Processing 92, 376-382.

Campbell CK, Johnson EM, Warnock DW. 2013 - Identification of pathogenic fungi. (2 ${ }^{\text {nd }}$ ed.) London, UK: Wiley-Blackwell.

Chang ST. 2006 - The World Mushroom Industry: trends and technological development. International Journal of Medicinal Mushrooms 8, 297-314.

Correia R, Magalhães M, Macêdo G. 2007 - Protein enrichment of pineapple waste with Saccharomyces cerevisiae by solid state bioprocessing. Journal of Scientific and Industrial Research 66, 259-262.

Duda-Chodak A, Tarko T. 2007 - Antioxidant properties of different fruit seeds and peels. Acta Scientiarum Polonorum Technologia Alimentaria 6, 29-36. 
Duhan JS, Kumar A, Tanwar SK. 2013 - Bioethanol production from starchy part of tuberous plant (potato) using Saccharomyces cerevisiae MTCC-170. African Journal of Microbiology Research 7, 5253-5260.

Duru CC, Uma NU. 2003 - Protein enrichment of solid waste from cocoyam (Xanthosoma sagittifolium) (L.) (Schott) cormel processing using Aspergillus oryzae obtained from cormel flour. African Journal of Biotechnology 2(8), 228-232.

Ellaiah P, Adinarayana K, Bhavani Y, Padmaja P, Srinivasulu B. 2002 - Optimization of process parameters for glucoamylase production under solid-state fermentation by a newly isolated Aspergillus species. Process Biochemistry 38, 615-620.

Ellis D, Davis S, Alexiou H, Handke R, Bartley R. 2007 - Descriptions of medical fungi ( $2^{\text {nd }}$ ed.) Adelaide, Australia.

El-Tayeb TS, Abdelhafez AA, Ali SH, Ramadan EM. 2012 - Effect of acid hydrolysis and fungal biotreatment on agro-industrial wastes for obtainment of free sugars for bioethanol production. Brazilian Journal of Microbiology 43(4), 1523-1535.

Ezekiel OO, Aworh OC. 2013 - Solid state fermentation of cassava peel with Trichoderma viride (ATCC 36316) for protein enrichment. International Journal of Nutrition and Food Engineering 7(3), 202-209.

Gao L, Sun MH, Liu XZ, Che YS. 2007 - Effects of carbon concentration and carbon to nitrogen ratio on the growth and sporulation of several biocontrol fungi. Mycological Research 111(1), $87-92$.

Gao L, Liu X. 2010 - Nutritional requirements of mycelial growth and sporulation of several biocontrol fungi in submerged and on solid culture. Microbiology 79, 612-619.

Gao L. 2014 - A preliminary study on nutritional requirements of nematophagous fungus ARF907 for mycelial growth. Journal of Yeast and Fungal Research 5(7), 92-95.

Gélinas P, Barrette J. 2007 - Protein enrichment of potato processing waste through yeast fermentation. Bioresource Technology 98(5), 1138-1143.

Guarro J, Pujol I, Aguilar C, Llop C, Fernández-Ballart J. 1998 - Inoculum preparation for in-vitro susceptibility testing of filamentous fungi. Journal of Antimicrobial Chemotherapy 42, 385387.

Iyayi EA, Losel DM. 2001 - Protein enrichment of cassava by-products through solid state fermentation by fungi. Journal of Food Technology in Africa 6(4), 116-118.

Kalogeris E, Christakopoulos P, Katapodis P, Alexiou A et al. 2003 - Production and characterization of cellulolytic enzymes from the thermophilic fungus Thermoascus aurantiacus under solid state cultivation of agricultural wastes. Process Biochemistry 38, 1099-1104.

Kjeldahl J. 1883 - "Neue Methode zur Bestimmung des Stickstoffs in organischen Körpern" (New method for the determination of nitrogen in organic substances), Zeitschrift für Analytische Chemie 22, 366-382.

Kumar J, Jain V, Shanker G, Srivastava A. 2003 - Utilization of fruit waste for citric acid production by solid state fermentation, Process Biochemistry 38, 1725-1729.

Kumar A, Duhan JS, Tanwar SK. 2013 - Screening of Aspergillus spp. for extra cellular $\alpha$-amylase activity. In: Khanna AK, Chopra G, Matta V, Singh, Bhutiani R (eds) Impact of global climate change on earth ecosystem. Biotech Books, New Delhi, pp 205-214.

Kumar A, Duhan JS, Gahlawat S, Gahlawat SK. 2014 - Production of ethanol from tuberous plant (sweet potato) using Saccharomyces cerevisiae MTCC-170. African Journal of Biotechnology 13(28), 2874-2883.

Kumar A, Sadh PK, Surekha Duhan JS. 2016 - Bio-ethanol production from sweet potato using coculture of saccharolytic molds (Aspergillus spp.) and Saccharomyces cerevisiae MTCC170. Journal of Advances in Biotechnology 6(1), 822-827.

Kumhomkul T, Panich-pat T. 2013 - Lead accumulation in the straw mushroom, Volvariella volvacea, from lead contaminated rice straw and stubble. Bulletin of Environmental Contamination and Toxicology 91, 231-234. 
Maiti S, Sarma SJ, Brar SK, Bihan YL et al. 2016 - Agro-industrial wastes as feed stock for sustainable bio-production of butanol by Clostridium beijerinckii. Food and Bioproducts Processing 98, 217-226.

Martin JGP, Porto E, Correa CB, Alencar SM et al. 2012 - Antimicrobial potential and chemical composition of agro industrial wastes. Journal of Natural Products 5, 27-36.

Mathew JJ, Vazhacharickal PJ, Sajeshkumar NK, Shaik HWKS. 2015 - Amylase production by Aspergillus niger in solid state fermentation using agro-industrial substrates. CIBTech Journal of Bio-Protocol 4, 5-9.

Mitchell DA, Doelle HW, Greenfield PF. 1988 - Agar plate growth studies of Rhizopus oligosporus and Aspergillus oryzae to determine their suitability for solid state fermentation. Applied Microbiology and Biotechnology 28, 598-602.

Mondal AK, Sengupta S, Bhowal J, Bhattacharya DK. 2012 - Utilization of fruit wastes in producing single cell protein. International Journal of Science, Environment and Technology $1(5), 430-438$.

Motte JC, Trably E, Escudié R, Hamelin J et al. 2013 - Total solids content: a key parameter of metabolic pathways in dry anaerobic digestion. Biotechnology for Biofuels 6, 164.

Murthy PS, Manonmani HK. 2008 - Bioconversion of coffee industry wastes with white rot fungus Pleurotus florida. Research Journal of Environmental Sciences 2, 145-150.

Mushimiyimana I, Tallapragada P. 2016 - Bioethanol production from agro wastes by acid hydrolysis and fermentation process. Journal of Scientific and Industrial Research 75, 383388.

Nagadesi PK, Arya A. 2013 - Effect of carbon and nitrogen on the growth of lignicolous fungi from Rathanmahal Wildlife Sanctuary. International Journal of Science and Nature 4(2), $237-$ 245.

Negi S, Banerjee R. 2009 - Optimization of extraction and purification of glucoamylase produced by A. awamori in solid state fermentation. Biotechnology and Bioprocess Engineering 14, 60-66.

Nigam PS, Gupta N, Anthwal A. 2009 - Pre-treatment of agro-industrial residues. In: Nigam PS, Pandey A (eds) Biotechnology for agro-industrial residues utilization. Springer, Heidelberg, pp 13-33.

Ofoefule AU, Uzodinma EO. 2009 - Biogas production from blends of cassava (Manihot utilissima) peels with some animal wastes. International Journal of Physical Sciences 4(7), 398-402.

Oliveira F, Souza CE, Peclat VROL, Salgado JM et al. 2017 - Optimization of lipase production by Aspergillus ibericus from oil cakes and its application in esterification reactions. Food and Bioproducts Processing 102, 268-277.

Omwango EO, Njagi ENM, Orinda GO, Wanjau RN. 2013 - Nutrient enrichment of pineapple waste using Aspergillus niger and Trichoderma viride by solid state fermentation. African Journal of Biotechnology 12(43), 6193 - 6196.

Paepatung N, Nopharatana A, Songkasiri W. 2009 - Bio-methane potential of biological solid materials and agricultural wastes. Asian Journal on Energy and Environment 10, 19-27.

Pandey A, Soccol CR. 2000 - Economic utilization of crop residues for value addition: a futuristic approach. Journal of Science and Industrial Research 59(1), 12-22.

Pandey A, Soccol CR, Nigam P, Soccol VT. 2000a - Biotechnological potential of agro-industrial residues. I: sugarcane bagasse. Bioresource Technology 74, 69-80.

Pandey A, Soccol CR, Nigam P, Soccol VT et al. 2000b - Biotechnological potential of agroindustrial residues. II: cassava bagasse. Bioresource Technology 74, 81-87.

Pandey A, Soccol CR, Nigam P, Brand D et al. 2000c - Biotechnological potential of coffee pulp and coffee husk for bioprocesses. Biochemical Engineering Journal 6, 153-162.

Parashar S, Sharma H, Garg M. 2014 - Antimicrobial and antioxidant activities of fruits and vegetable peels: a review. Journal of Pharmacognosy and Phytochemistry 3, 160-164.

Pitt JI, Hocking AD. 2009 - Fungi and food spoilage ( $3^{\text {rd }}$ ed.). New York, Springer. 
Randive SD. 2012 - Cultivation and study of growth of oyster mushroom on different agricultural waste substrate and its nutrient analysis. Advances in Applied Sciences and Research 3, 1938-1949.

Rivas B, Torrado A, Torre P, Converti A, Domínguez JM. 2008 - Submerged citric acid fermentation on orange peel autohydrolysate. Journal of Agriculture and Food Chemistry 56, 2380-2387.

Rodríguez-Couto S. 2008 - Exploitation of biological wastes for the production of value-added products under solid-state fermentation conditions. Biotechnology Journal 3, 859-870.

Sadh PK, Chawla P, Bhandari L, Kaushik R, Duhan JS. 2017a - In vitro assessment of bioaugmented minerals from peanut oil cakes fermented by Aspergillus oryzae through Caco-2 cells. Journal of Food Science and Technology 54, 3640-3649.

Sadh PK, Saharan P, Surekha, Duhan JS. 2017b - Bio-augmentation of phenolics and antioxidant activity of Oryza sativa by solid state fermentation with Aspergillus spp. International Food Research Journal 24(3), 1160-1166.

Sadh PK, Saharan P, Surekha, Duhan JS. 2017c - Bio-augmentation of antioxidants and phenolic content of Lablab purpureus by solid state fermentation with GRAS filamentous fungi. Resource-Efficient Technologies 3, 285-292.

Sadh PK, Duhan S, Surekha, Duhan JS. 2018 - Agro-industrial wastes and their utilization using solid state fermentation: a review. Bioresources and Bioprocessing 5, 1-15.

Saharan P, Sadh PK, Duhan JS. 2017 - Comparative assessment of effect of fermentation on phenolics, flavonoids and free radical scavenging activity of commonly used cereals. Biocatalysis and Agricultural Biotechnology 12, 236-240.

Saini JK, Saini R, Tewari L. 2015 - Lignocellulosic agriculture wastes as biomass feedstocks for second-generation bioethanol production: concepts and recent developments. 3 Biotech 5(4), 337-353.

Shah M, Reddy G, Banerjee R, Babu P, Kothari I. 2005 - Microbial degradation of banana waste under solid state bioprocessing using two lignocellulolytic fungi (Phylosticta spp. MPS-001 and Aspergillus spp. MPS-002), Process Biochemistry 40, 445-451.

Sharma G, Pandey R. 2010 - Influence of culture media on growth, colony character and sporulation of fungi isolated from decaying vegetable wastes. Journal of Yeast and Fungal Research 18, 157-164.

Siqueira FG, Martos ET, Silva R, Dias ES. 2011 - Cultivation of Pleurotus sajor-caju on banana stalk and Bahia grass based substrates. Horticultura Brasileira 29, 199-204.

Soccol CR, Vandenberghe LPS. 2003 - Overview of applied solid-state fermentation in Brazil. Biochemical Engineering Journal 13, 205-218.

Topakas E, Kalogeris E, Kekos D, Macris BJ, Christakopoulos P. 2004 - Production of phenolics from corn cabs by coupling enzymic treatment and solid state fermentation. Engineering in Life Sciences 4(3), 283-286.

Tsen YY, Chen MT, Lin CF. 2000 - Growth, pigment production and protease activity of Monascus purpureus as affected by salt, sodium nitrate, polyphosphate and various sugars. Journal of Applied Microbiology 88, 31-37.

Vastrad BM, Neelagund SE. 2012 - Optimization of process parameters for rifamycin b production under solid state fermentation from Amycolatopsis mediterranean MTCC 14. International Journal of Current Pharmaceutical Research 4, 101-108.

Villas-Boas S, Esposito E, Mendonça M. 2003 - Bioconversion of apple pomace into a nutritionally enriched substrate by Candida utilis and Pleurotus ostreatus, World Journal of Microbiology and Biotechnology 19, 461-467.

Wani AA, Sogi DS, Singh P, Khatkar BS. 2013 - Influence of watermelon seed protein concentrates on dough handling, textural and sensory properties of cookies. Journal of Food Science and Technology 52, 2139-2147.

Watanabe T. 2010 - Pictorial atlas of soil and seed fungi; morphologies of cultured fungi and key to species. ( $\left.3^{\text {rd }} \mathrm{Ed}\right)$. New York: CRC Press. 
Weshahy AA, Rao VA. 2012 - Potato peel as a source of important phytochemical antioxidant nutraceuticals and their role in human health. A review - Phytochemicals as Nutraceuticals Venketeshwer Rao, IntechOpen, Doi: 10.5772/30459.

Yafetto L, Osei-Bonsu V. 2017 - Ethnomycological survey of Cape Coast Metropolis, Ghana. Current Research in Environmental and Applied Mycology 7(4), 258-266. Doi $10.5943 / \mathrm{cream} / 7 / 4 / 2$.

Yafetto L. 2018 - Protein enrichment of cassava pulp by solid-state fermentation using Aspergillus niger. Studies in Fungi. 3(1): 7-18. Doi 10.5943/sif/3/1/2.

Yalemtesfa B, Alemu T, Santhanam A. 2010 - Solid substrate fermentation and conversion of orange waste into fungal biomass using Aspergillus niger KA-06 and Chaetomium spp KC06. African Journal of Microbiology Research 4, 1275-1281.

Yang SS. 1988 - Protein enrichment of sweet potato residue with amylolytic yeasts by solid-state fermentation. Biotechnology and Bioengineering 32(7), 886-890.

Yang SS. 1993 - Protein enrichment of sweet potato residue with co-culture of amylolytic fungi by solid-state fermentation. Biotechnology Advances 11(3), 495-505.

Yang SS, Jang HD, Liew CM, du Preez JC. 1993 - Protein enrichment of sweet potato residue by solid-state cultivation with mono- and co-cultures of amylolytic fungi. World Journal of Microbiology and Biotechnology 9(2), 258-264. 